\title{
Analisis Kualitas Layanan Perpustakaan Menggunakan Metode Kano Di Perpustakaan Universitas Kadiri
}

\author{
Mahmudatul Huda $^{(1)}$, Heribertus Budi Santoso ${ }^{(2)}$, Sri Rahayuningsih ${ }^{(3)}$ \\ ${ }^{(1,2,3)}$ Jurusan Teknik Industri, Fakultas Teknik, Universitas Kadiri \\ Email : mikailaayunda@gmail.com ${ }^{(1)}$
}

\begin{abstract}
Abstrak
Kegiatan perpustakaan yang langsung dirasakan oleh pengguna adalah pelayanan, karena pelayanan merupakan ujung tombak perpustakaan. Pada pelayanan inilah berlangsungnya hubungan antara pengguna dan penyedia jasa. Penelitian ini bertujuan untuk mengkategorikan atribut-atribut keunggulan dan kelemahan dari kualitas layanan perpustakaan Universitas Kadiri berdasarkan metode Kano. Penelitian ini menggunakan pendekatan kuantitatif jenis survey dengan metode deskriptif analitis. Hasil analisa penelitian menunjukkan bahwa layanan yang diberikan masih kurang. Kategori Must Be dari variabel tangible, reliability, responsiveness yang menjadi identifikasi kelemahan dan harus dilakukan peningkatan dan kategori one dimensional dari variabel assurance dan emphaty yang menjadi identifikasi keunggulan dan perlu dipertahankan. Selanjutnya dari perhitungan kekecewan dan kepuasan pengunjung didapatkan 62\% kepuasan pengunjung dan didapatkan $92 \%$ kekecewaan pengunjung. Kepuasan terbesar didapat dari atribut ke-25 yaitu petugas memberikan pelayanan dengan rapi, sopan dan ramah. Sedangkan atribut dengan nilai tingkat kepuasan konsumen terendah adalah atribut ke-17 yang masuk dalam kategori must-be, yaitu kesesuaian koleksi yang tersedia dan informasi yang ada. Artinya atribut ini memiliki pengaruh yang kecil terhadap kepuasan konsumen. Selanjutnya untuk kekecewaaan pengunjung didapatkan atribut ke 25 yaitu apabila petugas tidak memberikan pelayanan dengan rapi, sopan dan ramah. Dan untuk tingkat kekecewaan terkecil adalah atribut ke-1 yang tergolong kategori indifferent yaitu lokasi tata letak perpustakaan strategis.
\end{abstract}

Kata Kunci: Kualitas layanan, Perpustakaan, Metode Kano

\begin{abstract}
Library activities that are immediately felt by users are services, because service is the spearhead of the library. At this service the ongoing relationship between users and service providers. This study aims to categorize the attributes and weaknesses of service quality Kadiri University library based on the Kano method. This research uses quantitative survey types with analytical descriptive methods. The results of the research analysis showed that the services provided were still lacking. Categories must be of tangible variables, reliability, responsiveness that are considered weaknesses and must be improved and one-dimensional categories of assurance and empathy variables are profit and need to be improved. Furthermore, from the calculation of animal satisfaction and visitor satisfaction obtained $62 \%$ of visitor satisfaction and obtained $92 \%$ of visitor disappointment. The greatest satisfaction is obtained from the 25 th attribute, namely officers who provide services neatly, politely and friendly. While the attribute with the lowest customer satisfaction value is the 17 th attribute included in the must-be category, namely the suitability of available collections and available information. Indicates attributes that have little importance to customer satisfaction. Furthermore, for the disappointment visitors get the 25 th attribute, which is to deny not providing services
\end{abstract}


neatly, politely and friendly. And for the high level of disappointment is the 1st attribute classified as indifferent, namely the location of the strategic library layout.

\section{Keyword : Quality of service, Library, The Canoe Method}

\section{Pendahuluan}

Dalam dunia pendidikan, perpustakaan merupakan tempat belajar seumur hidup. Tugas dari perpustakaan untuk menyediakan, mengumpulkan, melestarikan, mengolah dan menyebarkan informasi yang diperlukan, baik itu dari tingkat dasar sampai ke perguruan tinggi [1],[2]. Sesuai dengan fungsinya perpustakaan dituntut untuk memberikan pelayanan yang berkualitas yaitu layanan yang dapat memenuhi kebutuhan dan harapan pengguna perpustakaan. Pengguna perpustakaan sebagai penerima layanan (service recipient) memiliki peran yang dominan dalam menentukan penilaian atas kinerja perpustakaan sebagai penyedia layanan (service provider) [3], [4]. Hal ini disebabkan karena penggunalah yang mengkonsumsi serta menikmati jasa layanan sehingga merekalah yang menentukan kualitas jasa [5], [6]. Kegiatan perpustakaan yang langsung dirasakan oleh pengguna adalah pelayanan, karena pelayanan merupakan ujung tombak perpustakaan [2],[7],[8] Pada pelayanan inilah berlangsungnya hubungan antara pengguna dan penyedia jasa. Pelayanan yang berkualitas merupakan harapan bagi setiap pengguna perpustakaan. Dengan kualitas jasa pelayanan yang diberikan dapat mendorong pengguna untuk selalu memanfaatkan jasa perpustakaan. Menurut [6], kualitas pelayanan adalah tingkat keunggulan yang diharapkan dan pengendalian atas tingkat keunggulan tersebut untuk memenuhi kebutuhan pengguna. Dengan kata lain, ada dua factor utama yang mempengaruhi kualitas pelayanan yaitu expected service (pelayanan yang diharapkan) dan perceived service (pelayanan yang diterima) [7], [9], [10]. Karena kualitas pelayanan berpusat pada upaya pemenuhan dari keinginan pengguna. Apabila pelayanan yang diterima atau dirasakan sesuai dengan yang diharapkan oleh pengguna perpustakaan, maka kualitas pelayanan dipersepsikan baik dan memuaskan. Jika jasa pelayanan yang diterima melampaui harapan pengguna, maka kualitas pelayanan dipersepsikan sebagai kualitas ideal. Tetapi sebaliknya, jika pelayanan yang diterima leih rendah dari yang diharapkan pengguna, maka kualitas pelayanan dipersepsikan buruk. Kualitas pelayanan harus dimulai dari kebutuhan pengguna dan berakhir pada tanggapan pengguna. Tanggapan pengguna terhadap kualitas pelayanan itu sendiri merupakan penilaian menyeluruh terhadap keunggulan suatu pelayanan. Menurut [6], analisa tingkat kinerja kualitas pelayanan di Universitas Kadiri dirasa cukup oleh mahasiswa. Metode Kano dikembangkan oleh Dr. Noriaki Kano dari Tokyo Riko University pada tahun 1984. Metode Kano bertujuan untuk mengkategorikan atribut-atribut produk maupun jasa seberapa baik atribut tersebut mampu memuaskan kebutuhan pelanggan. Salah satu metode sederhana namun mampu dalam meningkatkan produk dan layanan kepada pelanggan, metode ini suatu model yang dikelompokkan atribut-atribut dan dianalisa berdasarkan persepsi pelanggan, dan efeknya terhadap kepuasan pelanggan. Hasil analisa sangat membantu menciptaan suatu customer experience [5], [11]. Metode Kano juga mengklasifikasikan atribut-atribut produk, baik barang maupun jasa. Hubungan antara kepuasan pelanggan dan fasilitas pelayanan atau fungsi dari produk dan jasa sesuai diagram Kano.

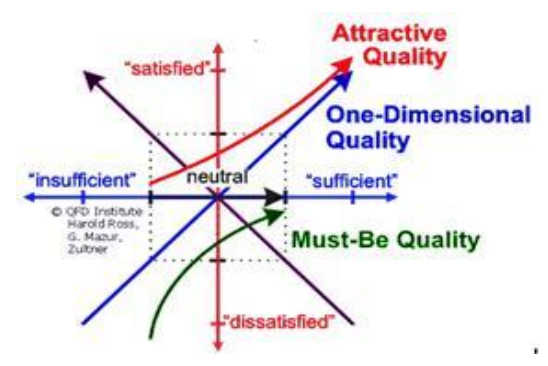

Gambar 1 Hubungan Kepuasan Pelanggan dan Fasilitas Pelayanan

Atribut-atribut tersebut dapat dibedakan menjadi beberapa kategori sebagai berikut [12], [13] : 
a. Atractivelexcitement needs. Yaitu tingkat kepuasan pelanggan akan meningkat seiring dengan meningkatnya kinerja atribut, namun penurunannya tidak akan menyebabkan penurunan tingkat kepuasan [14].

b. One Dimensional. Yaitu tingkat kepuasan pelanggan berhubungan linier dengan kinerja atribut, dimana peningkatan kinerja atribut akan meningkatkan kepuasan pelanggan dan menurunnya kinerja atribut akan menurunkan kepuasan pelanggan [15].

c. Must be/Basic Needs. Yaitu pelanggan menjadi tidak puas apabila kinerja dari atribut yang bersangkutan rendah tetapi kepuasan pelanggan tidak akan meningkat jauh diatas netral meskipun kinerja dari atribut tersebut tinggi. Kategori ini merupakan kebutuhan dasar yang harus dipenuhi oleh penyedia jasa kepada konsumennya [16].

d. Indifferent. Ini merupakan kategori yang tidak memberikan pengaruh pada kepuasan konsumen.

e. Reverse. Ini merupakan kebalikan dari kategori One dimensional yaitu derajat kepuasan lebih tinggi jika layanan tidak berlangsung semestinya [17].

f. Questionable. Yaitu kondisi ini kadangkala konsumen puas atau tidak puas jika layanan itu diberikan atau tidak diberikan [18].

Batasan yang digunakan pada penelitian ini antara lain : Objek penelitian adalah kualitas pelayanan pada perpustakaan Universitas Kadiri. Responden adalah pengunjung yang datang dan mendapatkan pelayanan di perpustakaan.

\section{Metode Penelitian}

Lokasi dan tempat penelitian ini dilakukan di kampus Universitas Kadiri tepatnya pada Perpustakaan Universitas Kadiri. Jalan Selomangleng No. 1, Kelurahan Pojok Kecamatan Mojoroto, Kota Kediri. Merupakan gambaran mengenai tahapan persiapan dan pelaksanaan yang dilakukan dalam penelitian. Langkah-langkah penelitian perlu disusun secara baik untuk mempermudah penyusunan laporan penelitian. Langkah tersebut antara lain :

1. Identifikasi masalah dan tujuan penelitian

Menentukan masalah apa yang terjadi pada obyek yang akan diteliti untuk dicari solusi atau pemecahan masalahnya. Selanjutnya menentukan apa yang menjadi tujuan dari penelitian yang akan dilakukan.

2. Menentukan Populasi dan Sampel

Menentukan banyaknya jumlah populasi dan menghitung jumlah sampel untuk memudahkan penelitian [19].

3. Penyebaran Kuesioner

Mencari informasi yang lengkap mengenai suatu masalah dan responden [17].

4. Pengumpulan Data

Mengumpulkan data yang dibutuhkan dan diambil dari obyek.

5. Pengujian Data

a. Uji Validitas [20]

- Jika data valid maka dilanjukan ke uji reliabilitas

- Jika data tidak valid maka kembali pada penyebaran kuesioner.

b. Uji Reliabilitas [21]

- Jika data reliabel maka dilanjutkan ke tahap berikutnya

- Jika data tidak reliabel maka kembali pada penyebaran kuesioner.

6. Identifikasi atribut dengan metode kano

Mengklasifikasikan atribut ke dalam kategori Kano yaitu antara lain (one dimensional, attractive, must be, indifferent, reverse,questionable) [12]

7. Analisis

Menganalisis hasil dari pengolahan data dan hasil identifikasi atribut [22]

8. Kesimpulan dan Saran

Membuat kesimpulan dan saran hasil identifikasi atribut. 


\section{Hasil Penelitian}

Dalam metode pengolahan data dilakukan tahapan sebagai berikut :

a. Uji Validitas

Untuk mengetahui sejauh mana ketepatan suatu alat ukur dalam melakukan pengkuran atas apa yang diukur. Uji Signifikasi dilakukan dengan membandingkan nilai $r$ Hitung dan $r$ Tabel untuk degree of freedom $(\mathrm{df})=\mathrm{n}-2$, dalam hal ini $\mathrm{n}$ adalah jumlah sampel. Jumlah Sampel pada penelitian ini adalah $(\mathrm{n})=50$ dan besarnya df dapat dihitung 50-2 $=48$, dengan $\mathrm{df}=48$ dan alpha 0,1 didapat $\mathrm{r}$ Tabel $=0,2353$. Bandingkan nilai correlated item - total correlation dengan hasil perhitungan $r$ Tabel. Jika $r$ Hitung > r Tabel dan nilai positif maka butir atau pertanyaan atau indikator tersebut Valid (Imam, G 2001:45)

b. Uji Reliabilitas

Untuk mengetahui tingkat ketepatan/tingkat presisi suatu ukuran atau alat pengukur karena syarat untuk kualifikasi suatu instrumen pengukur adalah konisten atau tidak berubah-ubah. Karena instrumen yang digunakan menggunakan jawaban berskala maka uji reliabilitas menggunakan Cronsbach Alpha.

c. Identifikasi keunggulan dan kelemahan Untuk menganalisa keunggulan dan kelemahan diperoleh dengan cara berikut yaitu :

d. Klasifikasi atribut berdasarkan metode Kano

1. Menentukan kategori atribut tiap responden berdasarkan

Tabel 1 Evaluasi Kano

\begin{tabular}{|c|c|c|c|c|c|c|}
\hline \multirow{3}{*}{$\begin{array}{l}\text { Kebutuhan } \\
\text { Konsumen }\end{array}$} & \multirow{3}{*}{$\begin{array}{l}\text { Kebutuhan } \\
\text { Konsumen }\end{array}$} & \multicolumn{5}{|c|}{ Disfungsional } \\
\hline & & 1 & 2 & 3 & 4 & 5 \\
\hline & & Suka & Mengharapkan & Netral & $\begin{array}{c}\text { Memberika } \\
\mathrm{n} \text { toleransi }\end{array}$ & $\begin{array}{l}\text { Tidak } \\
\text { suka }\end{array}$ \\
\hline \multirow{4}{*}{ 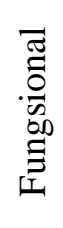 } & 1. Suka & Q & A & A & A & $\mathrm{O}$ \\
\hline & 2. Mengharapkan & $\mathrm{R}$ & $\mathrm{I}$ & $\mathrm{I}$ & $\mathrm{I}$ & $\mathrm{M}$ \\
\hline & 3. Netral & $\mathrm{R}$ & $\mathrm{I}$ & I & I & $\mathrm{M}$ \\
\hline & $\begin{array}{l}\text { 4. Memberikan } \\
\text { toleransi }\end{array}$ & $\mathrm{R}$ & I & I & I & M \\
\hline
\end{tabular}

Keterangan :

$\mathrm{Q}=$ Questionable (Diragukan)

$\mathrm{R}=$ Reverse (Kemunduran)

$\mathrm{A}=$ Attractive (Menarik)

$\mathrm{I}=$ Indefferent (Netral)

$\mathrm{O}=$ One Dimensional (Satu Ukuran)

$\mathrm{M}=$ Must be (Keharusan)

2. Menghitung jumlah masing-masing kategori kano dalam tap-tiap atribut.

3. Menentukan kategori kano tiap atribut dengan menggunakan Baluth's Formula (Walden) sebagai berikut [16]:

a. Jika jumlah nilai (one dimensional + attractive + must be) $>$ jumlah niai $($ Indifferent + reverse + questionable) maka grade diperoleh nilai paling maksimum dari (one dimensional,attractive, must be)

b. Jika jumlah nilai (one dimensional + attractive + must be) $<$ jumlah niai (Indifferent + reverse + questionable) maka grade diperoleh nilai paling maksimum dari (indifferent,reverse, questionable)

c. Jika jumlah nilai (one dimensional + attractive + must be $)=$ jumlah niai $($ Indifferent + reverse + questionable) maka grade diperoleh nilai paling maksimum dari (one dimensional,attractive, must be, indifferent, reverse ,questionable) 
Alasan menggunakan formula ini karena pada dasarnya model kano terdiri dari 3 kategori yaitu attractive, one dimensional dan must be. Akan tetapi respon pengunjung akan selalu ada dan muncul kategori indifferent,reverse dan questionable. Indifferent (netral), kategori dimana jika ada tidaknya layanan tidak akan berpengaruh pada kepuasan pengunjung. Reverse (kemunduran), derajat kepuasan pengunjung lebih tinggi jika layanan tidak berlangsung semestinya dibadingkan kepuasan terhadap layanan yang berjalan lebih baik. Questionable (diragukan), kadangkala pengunjung puas atau tidak puas jika layanan itu diberikan.

Analisis yang digunakan dalam penelitian ini adalah analisa kualitatif dan analisa kuantitatif.

a. Analisa Kualitatif

Data yang berupa angka tidak dapat dilakukan dengan operasi matematika. Pemahaman mengenaai masalah-masalah dalam kehdupan sosial berdasarkan kondisi realitas. Dengan pendekatan induktif. Analisa kualitatif meliputi :

1. Mengidentifikasi segala sesuatu yang dapat diberi berbagai macam nilai/ variabel-variabel keinginan siswa berdasarkan observasi untuk dimasukkan dalam kuesioner untuk membantu responden dalam menentukan pernyataan.

2. Menterjemahkan keinginan pelanggan dalam bahasa teknik (penentuan atributatribut/karakteristik tunggal untuk suatu obyek, obyek/kejadian). Mengidntiikasikan hubungan antara atribut (karakteristik) untuk mengetahui bagaimana pengaruh posiitif/negatif yang terjadi jika dilakukan perubahan suatu sifat terhadap sifat yang lain.

3. Menentukan atribut yang termasuk kategori keunggulan dan kelemahan.

4. Menentukan atribut yang termasuk metode kano.

b. Analisa Kuantitatif

Data berupa angka dapat dilakukan operasi matematika. Pengujian teori dan pendekatan deduktif. Analisa kuantitatif meliputi :

1. Menentukan jumlah kuesioner yang sah/ tidak cacat meliputi kelengkapan pengisian kuesioner, kelengkapan makna jawaban, konsisten antar jawaban (jawaban hanya satu untuk setiap pertanyaan) dan relevansi jawaban. Kemudian data yang masuk (data mentah) diringkas dalam tabel.

2. Menguji kesahihan dan keandalan kuesioner dengan analisa kesahihan dan keandalan dengan memakai Software SPSS [23].

3. Menghitung keunggulan dalam setiap atribut.

4. Menghitung jumlah masing-masing kategori kano dalam tiap-tiap atribut.

\section{Pembahasan}

Pengolahan data dalam penelitian ini diperoleh dari pengunjung yang menggunakan layanan perpustakaan melalui penyebaran kuesioner. Dalam pengisian kuesioner responden didampingi secara langsung untuk menjelaskan hal-hal yang tidak dimengerti oleh responden sehingga jawaban responden sesuai dengan maksud pertanyaan dalam kuesioner. Pengolahan data bertujuan untuk memahami apa yang terdapat dibalik data yang dipeoleh, diringkas menjadi suatu rumusan yang menyatu dan mudah dimengerti serta menemukan suatu pola umum yang timbul dari data tersebut, pengolahan data dilakukan dengan program Excel 2013 dan Statistical for Social Sciences (SPSS) versi 22.

Setelah didapatkan jumlah/nilai kategori Kano tiap-tiap atribut terhadap semua responden maka dilakukan penetuan kategori Kano dengan menggunakan rumus Baluth's Formula, seperti rumus diatas sehingga dihasilkan Kategori Kano yaitu 2 kategori atribut layanan indifferent , 21 atribut layanan must be dan 4 atribut layanan one dimensional dari 27 atribut yang ada, hal ini menunjukkan bahwa layanan yang diberikan belum sepenuhnya memenuhi harapan pengguna layanan. 
Tabel 2 Hasil Evaluasi Kano

\begin{tabular}{|c|c|c|c|c|c|c|c|}
\hline \multirow{2}{*}{ No } & \multirow{2}{*}{ Atribut } & \multicolumn{7}{|c|}{ Teknologi Kano } \\
\cline { 3 - 8 } & & $\mathrm{A}$ & $\mathrm{M}$ & $\mathrm{O}$ & $\mathrm{R}$ & $\mathrm{I}$ & $\mathrm{Q}$ \\
\hline 1 & $\mathrm{~T} 1$ & 6 & 8 & 11 & 2 & 16 & 7 \\
\hline 2 & $\mathrm{~T} 2$ & 4 & 12 & 7 & 4 & 14 & 9 \\
\hline 3 & $\mathrm{~T} 3$ & 3 & 20 & 15 & - & 7 & 5 \\
\hline 4 & $\mathrm{~T} 4$ & 3 & 20 & 15 & 1 & 9 & 2 \\
\hline 5 & T5 & 3 & 23 & 12 & 1 & 10 & 1 \\
\hline 6 & T6 & 2 & 21 & 12 & - & 13 & 2 \\
\hline 7 & T7 & 3 & 21 & 11 & - & 14 & 1 \\
\hline 8 & T8 & 2 & 31 & 10 & - & 6 & 1 \\
\hline 9 & T9 & 6 & 21 & 10 & - & 12 & 1 \\
\hline 10 & T10 & 6 & 20 & 10 & - & 13 & 1 \\
\hline 11 & T11 & 7 & 19 & 8 & 1 & 12 & 3 \\
\hline 12 & T12 & 4 & 17 & 9 & - & 14 & 6 \\
\hline 13 & R1 & 4 & 22 & 8 & 1 & 13 & 2 \\
\hline 14 & R2 & 5 & 19 & 10 & 1 & 15 & - \\
\hline 15 & R3 & 3 & 18 & 9 & 1 & 19 & - \\
\hline 16 & R4 & 4 & 19 & 8 & 1 & 18 & - \\
\hline 17 & R5 & 2 & 24 & 5 & - & 17 & 1 \\
\hline 18 & R6 & 1 & 23 & - & 1 & 14 & 1 \\
\hline
\end{tabular}

Sesuai dengan pendapat Sauerwein dalam [4] menyatakan kategori must be merupakan kategori dasar atau syara mutlak dari produk pelayanan yang seharusnya ada, jika tidak terpenuhi maka pengguna layanan menyatakan tidak puas dan sangat kecewa. Dan kategori indifferent merupakan atribut layanan yang tidak berpengaruh pada kepuasan konsumen. Sedangkan kategori one dimensional merupakan atribut layanan yang memenuhi harapan pengguna layanan, semakin tinggi tingkat layanan kinerja semakin tinggi tingkat kepuasan pelaggan. Hasil penelitian ini menunjukkan kategori kelemahan must be pada atribut layanan lebih banyak harus segera ditingkatkan menjadi rekomendasi prioritas tindakan perbaikan pihak manajemen perpustakaan.

Selanjutnya dilakukan perhitungan untuk menetukan kategori Kano yang paling berpengaruh cara perhitungannya adalah :

$$
\text { Jumlah Responden Kano }=\frac{\text { jumlah keseluruhan kategori Kano }}{\text { Jumlah pertanyaan tiap atribut }}
$$

Tabel 3 Pemetaan Kategori Kano yang Paling Berpengaruh

\begin{tabular}{|c|c|c|c|c|c|c|c|}
\hline \multirow{2}{*}{ No } & \multirow{2}{*}{ Variabel } & \multicolumn{7}{|c|}{ Jumlah Responden Perkategori Kano } \\
\cline { 3 - 8 } & & $\mathbf{A}$ & $\mathbf{M}$ & $\mathbf{O}$ & $\mathbf{R}$ & $\mathbf{I}$ & $\mathbf{Q}$ \\
\hline 1 & Tangible & 4 & 19 & 11 & 1 & 12 & 3 \\
\hline 2 & Reliability & 3 & 21 & 8 & 1 & 16 & 1 \\
\hline 3 & Responsive & 5 & 21 & 16 & 0 & 8 & 1 \\
\hline 4 & Assurance & 2 & 16 & 25 & 0 & 6 & 2 \\
\hline 5 & Emphaty & 4 & 18 & 21 & 0 & 7 & 2 \\
\hline
\end{tabular}




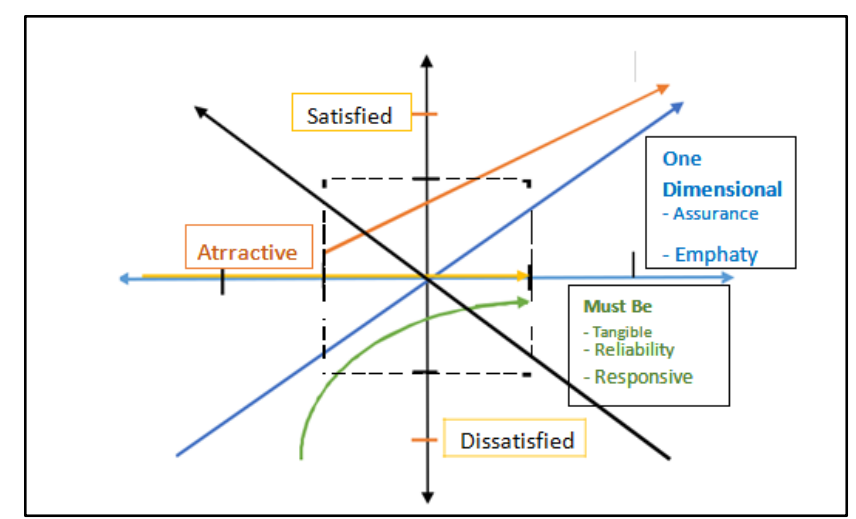

Gambar 2 Grafik Kategori KANO yang Paling Berpengaruh

Dari Tabel 3 dan Gambar 2 didapat atribut layanan yang paling berpengaruh terhadap kepuasan pengguna layanan yaitu :

a. Tangible, Reliability dan Responsive

Untuk dimensi Tangible, konsumen memilih kategori must be dengan jumlah tertinggi yaitu 19. Untuk dimensi Reliability konsumen memilih kategori must be dengan jumlah tertinggi yaitu 21. Untuk dimensi Responsive konsumen memilih kategori must be dengan jumlah tertinggi yaitu 21. Konsumen memilih kategori must be berarti semakin tinggi kinerja fasilitas dan layanan yang diberikan kepada konsumen berupa fisik, maka kepuasan konsumen tidak akan meningkat jauh diatas normal. Dengan kata lain pengguna layanan beranggapan kategori layanan ini sudah semestinya harus ada/syarat mutlak terpenuhi sehingga atribut layanan ini termasuk kategori atribut kelemahan. Tindakan prioritas perbaikan harus segera dilakukan oleh manajemen perpustakaan sebagai upaya meningkatkan pemenuhan semua kategori Kano.

b. Assurance dan Emphaty

Untuk dimensi Assurance, konsumen memilih kategori one dimensional dengan jumlah tertinggi yaitu 25. Sedangkan Untuk dimensi Emphaty, konsumen memilih kategori one dimensional dengan jumlah tertinggi yaitu 21. Artinya semakin tinggi kinerja, fasilitas dan layanan berkualitas yang diberikan, pengguna layanan semakin puas. Kategori ini mempunyai kinerja yang lebih baik/keunggulan sehingga harus bia dipertahankan.

Tabel 4 Tingkat Kepuasan dan Kekecewaan

\begin{tabular}{|c|c|c|c|}
\hline No & Kategori & Kepuasan & Kekecewaan \\
\hline 1 & I & 0,41 & $-0,46$ \\
\hline 2 & I & 0,30 & $-0,51$ \\
\hline 3 & M & 0,40 & $-0,78$ \\
\hline 4 & M & 0,38 & $-0,74$ \\
\hline 5 & M & 0,31 & $-0,73$ \\
\hline 6 & M & 0,29 & $-0,69$ \\
\hline 7 & M & 0,29 & $-0,65$ \\
\hline 8 & M & 0,24 & $-0,84$ \\
\hline 9 & M & 0,33 & $-0,63$ \\
\hline 10 & M & 0,33 & $-0,61$ \\
\hline 11 & M & 0,33 & $-0,59$ \\
\hline 12 & M & 0,30 & $-0,59$ \\
\hline 13 & M & 0,26 & $-0,64$ \\
\hline 14 & M & 0,31 & $-0,59$ \\
\hline 15 & M & 0,24 & $-0,55$ \\
\hline 16 & M & 0,24 & $-0,55$ \\
\hline 17 & M & 0,15 & $-0,60$ \\
\hline 18 & M & 0,23 & $-0,63$ \\
\hline
\end{tabular}


Tabel 4 Tingkat Kepuasan dan Kekecewaan (lanjutan)

\begin{tabular}{|c|c|c|c|}
\hline No & Kategori & Kepuasan & Kekecewaan \\
\hline 19 & M & 0,17 & $-0,57$ \\
\hline 20 & M & 0,41 & $-0,76$ \\
\hline 21 & M & 0,42 & $-0,72$ \\
\hline 22 & M & 0,37 & $-0,71$ \\
\hline 23 & M & 0,48 & 0,78 \\
\hline 24 & O & 0,52 & $-0,77$ \\
\hline 25 & O & 0,60 & $-0,92$ \\
\hline 26 & O & 0,51 & $-0,78$ \\
\hline 27 & O & 0,48 & 0,79 \\
\hline
\end{tabular}

Apabila nilai tingkat kepuasan mendekati 1, maka dapat diartikan bahwa atribut tersebut semakin mempengaruhi kepuasan pengguna layanan perpustakaan. Jika nilai semakin mendekati 0 , berarti atribut tersebut tidak mempengaruhi pengguna. Sedangkan bila tingkat kekecewaan mendekati nilai -1, itu artinya bahwa pengaruh kekecewaan tersebut akan sangat kuat bila atribut tersebut tidak terpenuhi dan bila mendekati 0 berarti atribut tersebut tidak berpengaruh terhadap kekecewaan pelanggan. Setelah didapatkan nilai tingkat kepuasan dan kekecewaan tersebut.

Dari Tabel 5 dapat dilihat, bahwa nilai tingkat kepuasan tertinggi ada pada atribut ke-25 yaitu petugas layanan bersikap ramah, sopan, dan rapi dalam memberikan pelayanan . Hal ini berarti semakin ramah, sopan dan rapi petugas layanan dalam memberikan pelayanan akan berpengaruh sangat kuat terhadap peningkatan kepuasan konsumen. Sedangkan atribut dengan nilai tingkat kepuasan konsumen terendah adalah atribut ke-17 yang masuk dalam kategori must-be, yaitu kesesuaian koleksi yang tersedia dan informasi yang ada. Artinya atribut ini memiliki pengaruh yang kecil terhadap kepuasan konsumen.

Sedangkan untuk nilai tingkat kekecewaan terbesar ada pada atribut ke-25, yaitu petugas layanan bersikap ramah, sopan, dan rapi dalam memberikan pelayanan. Hal ini berarti, konsumen akan merasa kecewa bila kontrol petugas layanan tidak memberikan pelayanan dengan ramah, sopan dan rapi. Dan untuk tingkat kekecewaan terkecil adalah atribut ke-1 yang tergolong kategori indifferent yaitu lokasi tata letak perpustakaan strategis. Hal ini berarti bahwa tanpa adanya atribut tidak akan memberikan dampak yang besar terhadap kekecewaan pelanggan.

\section{Kesimpulan}

Berdasarkan hasil pengumpulan, pengolahan dan analisa data yang telah dilakukan pada bab sebelumnya dapat disimpulkan bahwa :

1. Kualitas Pelayanan pada Perpustakaan Universitas Kadiri masih kurang. Dikarenakan identifikasi kelemahan lebih besar daripada identifikasi keunggulan. Seperti yang ditunjukkan hasil Analisa Metode kano yang didapat dua kategori kano yaitu Must Be identifikasi kelemahan dan One Dimensional identifikasi keunggulan. Pada kategori Must Be didapat hasil sebanyak 61 dan pada kategori One Dimensional didapat hasil sebanyak 46. Dan untuk tingkat kekecewaan (ketidakpuasan) mencapai $92 \%$ pada atribut yang masuk dalam kategori Must Be sedangkan untuk tingkat keunggulan (kepuasan) mencapai $60 \%$ pada atribut yang masuk dalam kategori One Dimensional.

2. Berikut atribut-atribut yang menjadi prioritas dan termasuk kategori keunggulan dan harus tetap dipertahankan kinerja fasilitas layanannya oleh Perpustakaan Universitas Kadiri dalam menentukan kebutuhan dan keinginan pelanggan berdasarkan Metode Kano antara lain :

a. Dimensi Assurance yaitu : Prosedur penerimaan siswa yang mudah dan cepat, proses belajar mengajar dijalankan dengan baik dan lancar, jadwal pelajaran dijalankan dengan tepat / disiplin, Proses belajar mengajar yang mudah dipahami dan dimengerti.

b. Dimensi Emphaty yaitu : Informasi petunjuk penataan yang diberikan jelas serta keluhan dan saran di tanggapi dengan baik. 


\section{Daftar Pustaka}

[1] P. Prijana and A. Yanto, "Analisis hubungan prestasi akademik mahasiswa dengan akses sumber informasi," Berk. Ilmu Perpust. dan Inf., vol. 14, no. 1, p. 87, 2018.

[2] M. Huda, H. Santoso, and S. Rahayuningsih, "Analisis Kualitas Layanan Perpustakaan Menggunakan Metode Kano Di Perpustakaan Universitas Kadiri," JATI UNIK J. Ilm. Tek. dan Manaj. Ind., vol. 1, no. 1, p. 30, 2017.

[3] N. Ghoniyah and Masurip, "Peningkatan Kinerja Karyawan Melalui Kepemimpinan, Lingkungan Kerja Dan Komitmen," J. Din. Manaj., vol. 2, no. 2, pp. 118-129, 2011.

[4] Sofyan dkk, "Pengaruh fasilitas dan kualitas pelayanan terhadap loyalitas , melalui kepuasan konsumen sebagai variabel intervening pada Star Clean Car Wash Semarang," Diponegoro J. Soc. Polit., pp. 1-12, 2013.

[5] E. Maulia R, A. Matondang, and R. Ginting, "Analisis Kepuasan Pelanggan Dengan Pendekatan Model Kano Serta Aplikasi Quality Function Deployment (Qfd) Untuk Meningkatkan Mutu Pelayanan Jasa Perbankan,” J. Tek. Ind. USU, vol. 1, no. 2, pp. 1-7, 2013.

[6] I. Safi'i, Sutriyono, and F. Handoko, "Kualitas Pelayanan di Tinjau Dari Prestasi Akademik Mahasiswa Studi Kasus Pada Universitas Kadiri," Teknol. dan Manaj. Ind., vol. Vol. 1 No., 2015.

[7] B. Bilgili, A. Erci, and S. Ünal, "Kano model application in new product development and customer satisfaction (adaptation of traditional art of tile making to jewelries)," Procedia - Soc. Behav. Sci., vol. 24, pp. 829-846, 2011.

[8] I. W. Taifa and D. A. Desai, "Student-defined quality by Kano model: A case study of engineering students in India," Int. J. Qual. Res., vol. 10, no. 3, pp. 569-582, 2016.

[9] J. Yin, X. (Jason) Cao, X. Huang, and X. Cao, "Applying the IPA-Kano model to examine environmental correlates of residential satisfaction: A case study of Xi' an," Habitat Int., vol. 53, pp. 461-472, 2016.

[10] M. Lukman and W. Wulandari, "Peningkatan Kualitas Produk Cokelat Dengan Integrasi Metode Kano Dan QFD,” J. Tek. Ind., vol. 19, no. 2, p. 190, 2018.

[11] I. P. Tama, W. Azlia, and D. Hardiningtyas, "Development of Customer Oriented Product Design using Kansei Engineering and Kano Model: Case Study of Ceramic Souvenir," Procedia Manuf., vol. 4, no. Iess, pp. 328-335, 2015.

[12] C.-H. Lin, P.-H. Chou, W. Chou, and T.-W. Chien, "Using the Kano model to display the most cited authors and affiliated countries in schizophrenia research," Schizophr. Res., 2019.

[13] F. C. Putra, "Analisis pengukuran tingkat kualitas pelayanan terhadap kepuasan pelanggan dengan metode service quality (servqual) yang diintegrasikan dengan metode importance performance analysis (ipa)," Univeristas Islam Indonesia, 2019.

[14] Q. Xu, R. J. Jiao, X. Yang, M. Helander, H. M. Khalid, and A. Opperud, "An analytical Kano model for customer need analysis," Des. Stud., vol. 30, no. 1, pp. 87-110, 2009.

[15] Y. Suh, C. Woo, J. Koh, and J. Jeon, "Analysing the satisfaction of university-industry cooperation efforts based on the Kano model: A Korean case," Technol. Forecast. Soc. Change, vol. 148, p. 119740, 2019.

[16] L. He, W. Song, Z. Wu, Z. Xu, M. Zheng, and X. Ming, "Quantification and integration of an improved Kano model into QFD based on multi-population adaptive genetic algorithm," 
Comput. Ind. Eng., vol. 114, pp. 183-194, 2017.

[17] I. Rahmayuni, H. Humaira, and D. Defni, "Pemanfaatan Metode Kano Untuk Menilai Tingkat Kepuasan Pengguna Terhadap Fungsionalitas Sistem Informasi Kepegawaian (Studi Kasus: AKNP Pelalawan)," INOVTEK Polbeng - Seri Inform., vol. 1, no. 2, p. 133, 2016.

[18] M. M. RASHID, “A REVIEW OF STATE-OF-ART ON KANO MODEL FOR RESEARCH DIRECTION,” Int. J. Eng. Sci. Technol., vol. 2, no. 12, pp. 7481-7490, 2010.

[19] D. Budijanto, "Populasi, Sampling, dan Besar Sampel," Kementeri. Kesehat. RI, 2013.

[20] P. D, “Belajar Cepat Olah Data Statistik dengan SPSS,” in Uji Validitas dan Reliabilitas, 2012.

[21] F. Yusup, "Uji Validitas dan Reliabilitas Instrumen Penelitian Kuantitatif," J. Tarb. J. Ilm. Kependidikan, 2018.

[22] I. Safi'i, "Klasifikasi Atribut Pelayanan Mobile Banking dengan Kano Model Berdasarkan Dimensi E-Servqual," J. Sist. dan Manaj. Ind., vol. 2, no. 2, p. 77, 2018.

[23] A. Field, Discovering statistics using IBM SPSS statistics. 2013. 